DOI: $10.36910 / 6775-2524-0560-2020-39-33$

УДК: 004.01

Сіваковська Олена Миколаївна, к.т.н., https://orcid.org/0000-0002-9300-0039

Ліщина Валерій Олександрович, к.т.н., доцент,

https://orcid.org/0000-0002-2371-3850

Ящук Андрій Анатолійович, к.т.н.,

https://orcid.org/0000-0003-4872-7949

Матвіїв Юрій Ярославович, д.т.н., доцент,

https://orcid.org/0000-0002-2236-2200

Повстяна Юлія Славомирівна, к.т.н., доцент.

https://orcid.org/0000-0001-5426-4157

Луцький національний технічний університет, м. Луцьк, Україна

\title{
АНАЛІЗ ОСОБЛИВОСТЕЙ СТАНДАРТИЗАЦІЇ ПРОГРАМНИХ ПРОДУКТІВ ТА РОЗПОДІЛЕНИХ СИСТЕМ КЕРУВАННЯ
}

Сіваковська О. М., Ліщина В. О., Ящук А. А, Матвіїв Ю. Я., Повстяна Ю. С. Аналіз особливостей стандартизації програмних продуктів та розподілених систем керування. Здійснено аналіз становлення світової стандартизації. Означено етапи створення міжнародних організацій зі стандартизації. Розглянуто найактуальніші стандарти програмних продуктів та розподілених систем керування. Обгрунтовано переваги та недоліки процесу стандартизації.

Ключові слова: стандарти, стандартизація, управління якістю, контроль, виробництво, технології.

\begin{abstract}
Сиваковская Е. Н., Лищина В. А., Ящук А. А, Матвиив Ю. Я., Повстяная Ю. С. Анализ особенностей стандартизации программных продуктов и распределенных систем управления. Осуществлен анализ становления мировой стандартизации. Отмечено этапы создания международных организаций по стандартизации. Рассмотрены актуальные стандарты программных продуктов и распределенных систем управления. Обоснованы преимущества и недостатки процесса стандартизации.
\end{abstract}

Ключевые слова: стандарты, стандартизация, управление качеством, контроль, производство, технологии.

Olena Sivakovska. Valerii Lishchyna, Andrii Yashchuk, Yurii Matviiv, Yuliia Povstiana. Analysis of Features of Software Standardization and Distributed Control Systems. The analysis of formation of world standardization is carried out. The stages of creation of international standardization organizations are marked. Current standards of software products and distributed control systems are considered. The advantages and disadvantages of the standardization process are substantiated too.

Keywords: standards, standardization, quality management, control, production, technologies.

Постановка проблеми. Сучасні умови бізнесу та ринку змушують кожне підприємство запроваджувати дієвий комплексний механізм управління якістю продукції та дотримуватись його вимог. Визначальними елементами цього специфічного менеджменту, що справляють найбільш істотний вплив на процес постійного забезпечення виробництва й постачання на ринок конкурентоспроможної продукції є стандартизація та сертифікація продукції.

Стандартизація - це встановлення й застосування єдиних правил 3 метою впорядкування діяльності в певній галузі. Здійснюється вона за певними принципами, і результати стандартизації відображаються в спеціальній нормативно-технічній документації [1].

Аналіз останніх досліджень та публікацій. Значну роль у виготовленні конкурентоспроможної якісної продукції, економному використанні ресурсів як основи сталого розвитку національної економіки відіграє стандартизація. Саме стандартизація є важливою частиною економічної політики розвинутих держав, потужним представником національних інтересів на міжнародному ринку.

Постійний систематизований розвиток напрямків стандартизації повинен стати невід’ємною частиною програм наукових досліджень, просування нових технологій. Міжнародні стандарти допомагають упорядкувати відносини між різними країнами з економічних і наукових питань та уникати додаткових витрат на отримання сертифікатів або проведення багаторазових випробувань [2].

Питаннями, пов'язаними 3 управлінням якістю продукції, знайшли відображення в працях вітчизняних і зарубіжних авторів, зокрема А.О. Болотнікова, Л.С. Кириченка, В.М. Мазура, Н.Г. Салухіної, А.А. Шапошникова та ін.

Виклад основного матеріалу й обгрунтування отриманих результатів дослідження. Стандартизація бере свої витоки ще з 200-х рр. до н. е. Перший китайський імператор Цінь Ши Хуанг 
(260 - 210 рр. до н. е.) стандартизував не тільки китайські символи, але і систему одиниць і вимірювань, а також валюту та ширину осей візка.

Процес війни теж долучився до становлення стандартизації. Більше 2500 років тому Геракліт заявив: «Війна є батьком і царем усіх речей». В Громадянській війні США (1861 - 1865) однією 3 причин перемоги Союзу над Півднем була стандартизація його залізничних колій. Проблема полягала в різній ширині залізничних колій. Залізнична мережа противника в основному мала широкий формат колії, а Північна Кароліна та Вірджинія мали стандартні колії. Південні залізниці на захід від Міссісіпі дуже відрізнялися форматом колій, роблячи їх ізольованими та від'єднаними.

Під час громадянської війни уряд Союзу визнав військово-економічні переваги наявності стандартизованої колії. Уряд працював 3 залізницями, щоб сприяти використанню найбільш поширеної на той час залізничної колії в США, яка була за розміром 4 фути і 8 1⁄2 дюйма, що бере свій початок з Англії. Ця магістраль була погоджена для використання на Трансконтинентальній залізниці в 1864 році, і до 1886 року стала американським стандартом.

Іншим прикладом стандартизації під час воєн стали стандартизовані частини гвинтівки, що зробили їх взаємозамінними між даними типами зброї. Це була революційна ідея від Томаса Джефферсона та Елі Вітні, який був інженером-машиністом наприкінці XVIII століття. Також одним із ключових органів заснування стандартизації стала DIN (Німецька національна організація зі стандартизації) у 1917 р., яка на той час мала військовий досвід. Німецька промисловість хотіла оптимізувати виробництво під час Першої світової війни (1914 - 1918 рр.), оскільки велась і матеріальна битва між Німеччиною та Францією.

Існують також соціальні приклади успішної стандартизації. У 1904 році в Балтиморі спалахнула пожежа. Підкріплення з Нью-Йорка, Філадельфії та Вашингтона приїхали до Балтімору для боротьби з полум'ям. Після прибуття вони зрозуміли, що їх пожежні шланги не можуть бути підключені до пожежних гідрантів. У зв'язку з «отриманим уроком», США започаткували реалізацію багатьох проектів зі стандартизації.

У 1904 р. було створено Американський національний інститут стандартів (ANSI). Кількома роками раніше був заснований також Британський інститут стандартизації (BSI). Зростання міжнародного бізнесу, що вимагало стандартизації у всьому світі, призвело до народження Міжнародної електротехнічної комісії (IEC). Перше засідання відбулося в 1906 році. Спочатку іiі розташування знаходилося в Лондоні (Великобританія), а згодом комісія переїхала до своєї нинішньої штаб-квартири в Женеві в 1948 році.

Роком раніше, 25 країн заснували Міжнародну організацію зі стандартизації (ISO) для сприяння розвитку стандартизації і суміжних видів діяльності у світі 3 метою забезпечення міжнародного обміну товарами і послугами, а також розвиток співробітництва в інтелектуальній, науково-технічній і економічній галузях [3].

Попередник ISO був створений набагато раніше, у 1926 році, але його функціонування призупинилося під час Другої світової війни.

Сьогодні розподіл за класифікаційними ознаками - це уже історія, оскільки електрообладнання використовується в багатьох галузях промисловості і його потрібно стандартизувати. ISO також стандартизує електроніку, особливо для галузей, які не мають електричних витоків. Спочатку автомобілі не належали до електричної чи електронної сфери, ось тоді CAN і стандартизувався автомобільними технічними комітетами ISO.

ISO - міжнародна організація, метою діяльності якої є ратифікація стандартів, розроблених спільними зусиллями делегатів від різних країн [3]. Члени організації щорічно збираються на Генеральній Асамблеї, щоб обговорити стратегічні цілі ISO. Центральний секретаріат координує діяльність 3 стандартизації та публікує стандарти ISO. С 250 технічних комітетів та тисячі підкомітетів, робочих груп та оперативних груп.

Міжнародна електротехнічна комісія (IEC) має аналогічну кількість технічних працівників. Близько 10000 фахівців 3 електротехніки та електроніки в промисловості, уряді, академіях, дослідницьких лабораторіях та інших, зацікавлених у цій темі, що розробляють стандарти. Стандарти IEC мають число в межах від 60000 до 79999. IEC складається з членів, котрі називаються національними комітетами (НК). Кожна НК представляє електротехнічні інтереси своєї країни.

Міжнародна організація стандартизації (ISO) в рамках Технічного комітету ТС97 (сьогодні це ISO / IEC JTC1) також працювала над створенням мовних реляційних баз даних.

У 80-х роках як ANSI, так і ISO затвердили стандарти SQL (ANSI - в 1986 р., а ISO - на початку 1987 р.). Надалі з 1989 року обидві організації працювали над новими стандартами SQL, що призвело до появи стандарту SQL-92 (рис. 1). 


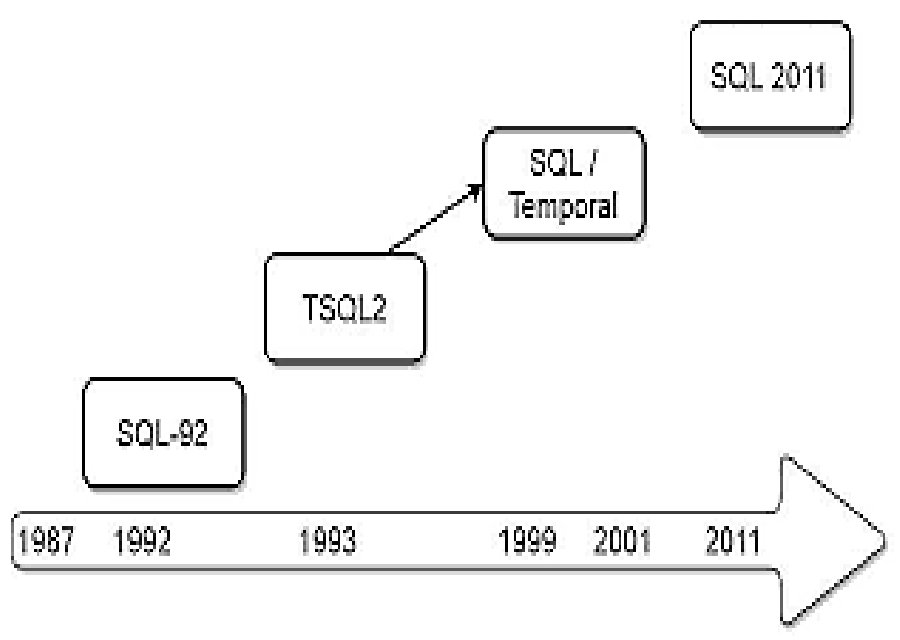

Рисунок 1 - Становлення стандарту SQL

В якості ще одного прикладу становлення стандартизації можна навести появу нині популярного UML (Unified Modeling Language). Основні розробки за методами об'єктноорієнтованого аналізу і проектування з'явилися між 1988 і 1992 роках. До 1994 р була велика кількість неформальних лідерів розробників-практиків (близько півтора десятка), які просували свої методології.

Усі їхні методики були схожі між собою, лише відмінності між ними полягали у другорядних деталях. Нависала розмова про стандартизацію. Команда з OMG намагалася розглянути проблему стандартизації, але у відповідь отримала відкритий лист з протестом від всіх авторів. У 1996 р. три провідних фахівці в області об'єктно-орієнтованого аналізу і проектування Джеймс Рамбо, Гра-ді Буч, Івар Якобсон об'єдналися. На світ з'явився Уніфікований метод версії 0.8. А в 1996 р. ці фахівці працювали над своїм методом, який отримав назву Unified Modeling Language. У січні 1997 р. piзні організації представили свої пропозиції по стандартизації методів, що передбачають в першу чергу можливість обміну інформацією між різними моделями. В результаті цієї праці сьогодні ми маємо єдину пропозицію - стандарт UML (рис. 2).

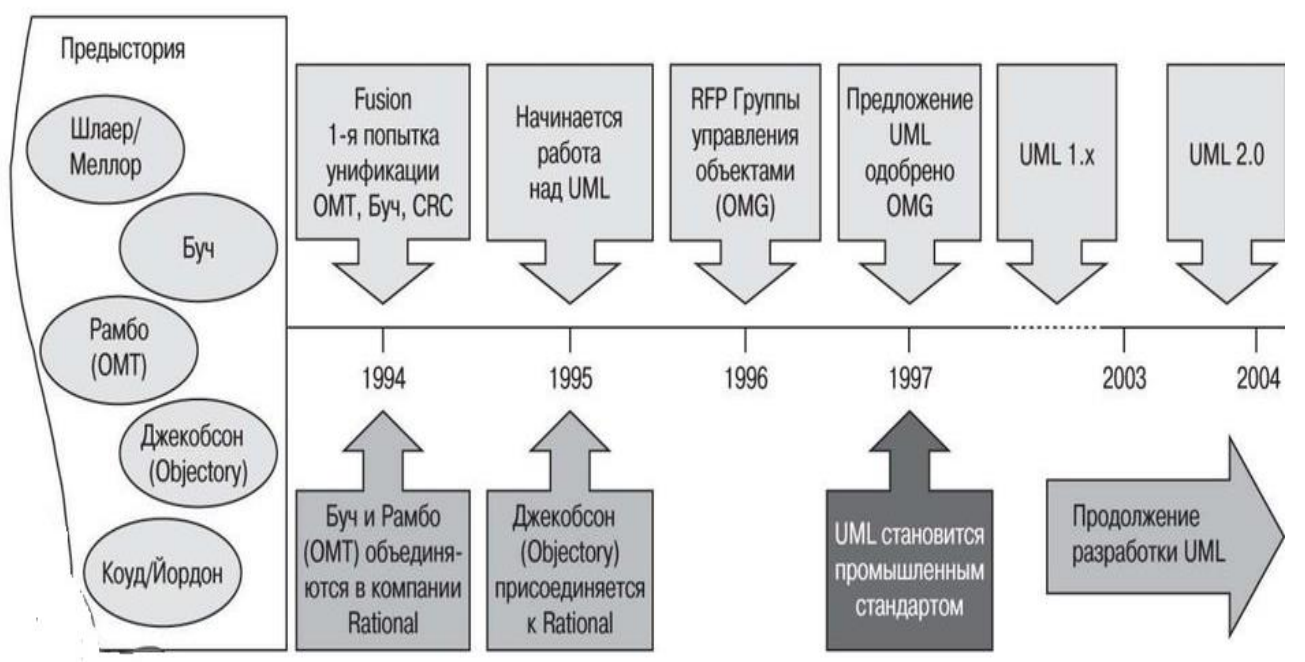

Рисунок 2 - Становлення стандарту UML 
Варто також взяти до уваги CAN-стандарти, пов'язані з ISO та IEC. Протокол CAN вперше був описаний у специфікації, опублікованій Bosch. Тому все ще багато людей з тих пір використовують терміни "CAN 2.0A" i "CAN 2.0B". Однак у 1993 році був випущений стандарт ISO 11898, замінивши «своїх попередників», включаючи специфікацію Bosch. Стандарт ISO містив рівень зв'язку даних CAN i високошвидкісну передачу CAN. У 1995 році стандарт ISO 11898 був розширений доповненням, що описує формат розширеного кадру за допомогою 29-бітного ідентифікатора CAN. Через десять років після публікації ISO 11898, документ було розділено на частини. Перша частина містила рівень зв'язку даних та фізичні сигнали, а друга частина стандартизувала швидкісну передачу. Передача несправності та малопотужна передача перейшла в стандарт ISO 11898-3. Одночасно ISO розпочала стандартизацію взаємодії (зв'язку) вантажівки з причепом на базі CAN. Результати визначені у серії ISO 11992, яка включає, власне, фізичне рішення передачі та протокол вищого рівня на основі J1939. Ця серія також спеціалізується на групах параметрів передачі (сигналах, зібраних в повідомлення CAN). Усі ці стандарти публікуються під дахом Технічного комітету (TC) 22. В рамках цього ТС також існує стандартизований транспортний протокол ISO (ISO 15765-2), який слугує базою для декількох стандартів (ISO 15765-4), пов'язаних 3 діагностикою викидів на основі CAN. Стандарт ISO 14229-3 базується на передачі діагностичних повідомленнях по локальній мережі контролера через CAN [4]. Ще одна серія, пов'язана з CAN, - це ISO 16844, що стандартизує тахографічну комунікацію для комерційних транспортних засобів. Цей стандарт посилається на європейські регламенти, але його промисловість не дуже любить, особливо це стосується далекобійників. Вони не люблять, щоб за ними велося спостереження в «електронному вигляді».

Одразу після 2000 року Bosch почав розширювати протокол CAN за допомогою протоколу, керованого часом. Питання про те, чи це протокол сеансового рівня, чи він взагалі не входить в протоколи взаємозв'язку відкритих систем (OSI), залишається без відповіді. Але він був стандартизований в ISO 11898-4 і відомий як TTCAN. На сьогоднішній день він не добився успіху в галузі. Деякі виробники чіпів реалізували його, але він не використовується.

Те ж саме сталося зі стандартом ISO 15745-2-2, що описує базову структуру XML для мереж на основі CAN; він також ніколи не застосовувався в системах промислової автоматизації. Це один із стандартів, що використовується лише для оформленням документів.

Не можна не згадати про CEN та Cenelec, європейські органи зі стандартизації, що були створені відповідно у 1961 та 1973 роках. Сьогодні вони працюють у тісній співпраці з IEC та ISO, щоб уникнути подвійної стандартизації. Або іншими словами, вони не намагаються «винаходити колесо».

Сьогодні ми не можемо уявити нашого життя без комп’ютерів та програмних засобів. Варто зупинитися і на цій невід'ємній сфері нашого життя. Термін "стандарти розробки програмного забезпечення" майже став оксимороном. Виробникам та розробникам комп'ютерів доводиться конкурувати на дуже високих рівнях, а наявність декількох фірмових вигадок часто є єдиною реальною перевагою одного розробника перед іншим. Тому утопія комп'ютерного світу, де все відповідає набору стандартів, ніколи не буде лише мрією. Однак $є$ певні інші стандарти, які стають критичними, яких слід дотримуватися, якщо ви бажаєте конкурувати у світі фінансів та фінансових систем.

У 60-і і 70-і роки XX століття створення стандартів ставило користувачів в залежне від виробників становище при використанні основних засобів обробки даних і телекомунікацій. Важливий аспект сьогоднішньої роботи зі стандартизації - подолання цієї залежності через просування стандартних інтерфейсів. Довгий час такими стандартами були SQL (Structured Query Language) і мова діаграм Д. Росса SADT (Structured Analysis and Design Technique) [5].

Стандарт розробляється при дотриманні правил консенсусу в процесі відкритої дискусії, в якій кожен має можливість взяти участь. Жодна група не може діяти незалежно, створюючи стандарти для промисловості. Якщо будь-яка група постачальників створить стандарт, що не враховує вимоги користувачів, вона зазнає невдачі. Те ж саме відбувається, якщо користувачі створюватимуть стандарт, з яким не можуть або не будуть погоджуватися постачальники, - цей стандарт також не буде успішним.

Стандарти не можуть бути змінені, не пройшовши процес узгодження під контролем організації, що розробляє стандарти. Стандарти OSI (Open Systems Interconnection), Ethernet, POSIX, SQL і більшість стандартів мов - приклади такого роду стандартів. 
Якщо говорити відверто, то можна сказати, що всі стандартизаційні заходи керуються інтересами окремих осіб або компаній - іноді і обох. Стандартизація має не лише технічний вимір; вона також має політичний характер.

Процес стандартизації іноді повільний порівняно з розвитком технології. Через це технології часто впроваджуються спочатку та стандартизуються пізніше. Стандартизація проходить повільно, оскільки всі сторони повинні мати можливість коментувати надані проекти та пропозиції. 3 позитивного боку, повільний процес уникає стандартизації технології, яка незабаром знову зникає.

Звичайно, процес стандартизації не повинен бути настільки повільним, щоб документ ніколи не публікувався. Тому ISO та IEC встановлюють терміни виконання проектів, які повинні бути дотримані. Однак читати стандарти нудно, особливо якщо ви не знайомі 3 конкретною мовою стандартизації. Але нам потрібні ці формальні правила щодо того, як писати стандарти. Нам потрібен стандарт, який говорить нам, як створити стандарти. Однією з причин є уникнення непорозумінь та неправильних тлумачень при перекладі стандарту на інші мови, крім двох офіційних: англійської та французької.

Висновки та перспективи подальших досліджень. Стандартизація достатньо ефективний засіб для оптимізації виробництва та посилення конкурентних позицій на ринку. У сучасному світі стандарти існують у динамічному та змінному середовищі. Стандартизація і сертифікація $є$ важливим при виході продукції на нові конкуруючі ринки, що підвищують престиж підприємства, а також іiі конкурентоспроможність. Одним із перспективних напрямків подальшої роботи у цій сфері $\epsilon$ детальне вивчення досвіду роботи у національних міжнародних організаціях зі стандартизації. Аналіз та дослідження міжнародних стандартів допоможе в становленні української стандартизації та управлінні якістю продукції сучасного ринку.

\section{Список бібліографічного опису}

1. Стандартизація та сертифікація продукції (2015) Економіка і підприємництво, менеджмент: електрон. версія підручника, URL : https://pidruchniki.com/80409/ekonomika/yakist_konkurentospromozhnist_produktsiyi (дата звернення: 30.04.2020). АСМ.

2. Зосереджуючись на майбутньому. Німецька стратегія стандартизації (2010) Стандартизація, сертифікація, якість, № 5, C. 23-28. ACM.

3. Міжнародна організація зі стандартизації (2019) Вікіпедія: віл. енцикл., URL : https://uk.wikipedia.org/wiki/\%D0\%9C\%D1\%96\%D0\%B6\%D0\%BD\%D0\%B0\%D1\%80\%D0\%BE\%D0\%B4\%D0\%BD\%D 0\%B0_\%D0\%BE\%D1\%80\%D0\%B3\%D0\%B0\%D0\%BD\%D1\%96\%D0\%B7\%D0\%B0\%D1\%86\%D1\%96\%D1\%8F_\%D0 \%B7\%D1\%96_\%D1\%81\%D1\%82\%D0\%B0\%D0\%BD\%D0\%B4\%D0\%B0\%D1\%80\%D1\%82\%D0\%B8\%D0\%B7\%D0\%B 0\%D1\%86\%D1\%96\%D1\%97 (дата звернення: 30.04.2020). АCM.

4. ГОСТ Р ИСО 15765-1-2014 (2015) Транспорт дорожный. Передача диагностических сообщений по локальной сети контроллера (DoCAN), Ч. 1, Москва, 12 с. АCM.

5. Стандарты в области программного обеспечения (2020) Лекции по дисциплине Сертификация и стандартизация, URL: https://werr.ru/standartizaciya2.php (дата звернення: 30.04.2020). ACM.

\section{References}

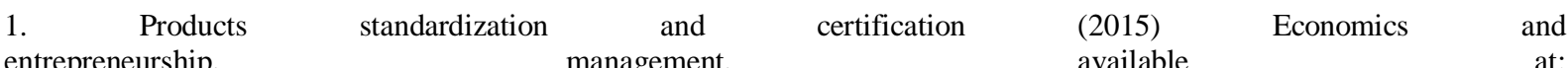
https://pidruchniki.com/80409/ekonomika/yakist_konkurentospromozhnist_produktsiyi (accessed 30 April 2020). ACM.

2. Focusing on the future. German standardization strategy (2010), Standardization, Certification, Quality, N 5, pp. $23-28$. ACM.

3. International Organization for Standardization (2019) Wikipedia, available at: https://uk.wikipedia.org/wiki/\%D0\%9C\%D1\%96\%D0\%B6\%D0\%BD\%D0\%B0\%D1\%80\%D0\%BE\%D0\%B4\%D0\%BD\%D 0\%B0_\%D0\%BE\%D1\%80\%D0\%B3\%D0\%B0\%D0\%BD\%D1\%96\%D0\%B7\%D0\%B0\%D1\%86\%D1\%96\%D1\%8F_\%D0 \%B7\%D1\%96\%D1\%81\%D1\%82\%D0\%B0\%D0\%BD\%D0\%B4\%D0\%B0\%D1\%80\%D1\%82\%D0\%B8\%D0\%B7\%D0\%B $0 \% \mathrm{D} 1 \% 86 \% \mathrm{D} 1 \% 96 \% \mathrm{D} 1 \% 97$ (accessed 30 April 2020). ACM.

4. GOST R ISO 15765-1-2014 (2015) Road transport. Transmission of diagnostic messages on the local area network of the controller (DoCAN), P. 1, Moscow, 12 p. ACM.

5. Software Standards (2020) Lections in the discipline "Certification and Standardization", available at: https://werr.ru/standartizaciya2.php (accessed 30 April 2020). ACM. 